Article

\title{
Ensuring Employee Job Security When Implementing Changes in the Company: A Case Study of Lithuanian Industry
}

\author{
Asta Valackiene ${ }^{1}$, Ieva Meidute-Kavaliauskiene ${ }^{2, *}$ and Renata Činčikaitè ${ }^{2}$ \\ 1 Institute of Business and Economics, Faculty of Public Governance and Business, \\ Mykolas Romeris University, Ateities Street 20, Room C-V-509, LT-08303 Vilnius, Lithuania; avala@mruin.eu \\ 2 General Jonas Žemaitis Military Academy of Lithuania, Šilo str. 5A, LT-10322 Vilnius, Lithuania; \\ renata.cincikaite@lka.lt \\ * Correspondence: ieva.meidute@lka.lt; Tel.: +370-6998-6847
}

Citation: Valackiene, A.; MeiduteKavaliauskiene, I.; Činčikaitè, R. Ensuring Employee Job Security When Implementing Changes in the Company: A Case Study of Lithuanian Industry. Sustainability 2021, 13, 8383. https://doi.org/ $10.3390 /$ su13158383

Academic Editor: Živilè Stankevičiūtè

Received: 21 May 2021

Accepted: 23 July 2021

Published: 27 July 2021

Publisher's Note: MDPI stays neutral with regard to jurisdictional claims in published maps and institutional affiliations.

Copyright: (C) 2021 by the authors Licensee MDPI, Basel, Switzerland. This article is an open access article distributed under the terms and conditions of the Creative Commons Attribution (CC BY) license (https:// creativecommons.org/licenses/by/ $4.0 /$ )

\begin{abstract}
The process of companies undertaking adaptation in the face of changing conditions that have been influenced by factors such as globalization, technological changes, environmental changes, competition, political decisions, worker mobility, population structure, and so on is one of the major challenges of modern corporate governance. Changes in a company are inevitable, but they do not always directly correlate with employees' sense of security, including whether an employee feels safe about their workplace, income, or future roles in the company in the face of potential changes. There is an inverse relationship between employees' sense of security and their time spent with the company. One way of managing this that can help to ensure a sense of security for employees within the company is to directly involve them in the process of implementing changes in the organization. The main goal of this paper is to highlight the principal aspects of employee engagement in change management processes and to gain an increased level of understanding in terms of the implementation of change at the organizational level by involving employees. Research methods: a systematic and comparative analysis of concepts and methods that have been published in the available scientific literature, statistical processing, an instrumental case study, interviews, surveys, and a content analysis of strategic documents, followed by modeling. The theoretical contribution of the paper demonstrates construction of methodology guided by the emergent perspective and new theoretical insights on professional discourse. Practical input shows that employee involvement in change processes is directly related to the speed of strategic change in the company.
\end{abstract}

Keywords: employee job security; implementation of changes; employee involvement; theoretical matrix; modeling

\section{Introduction}

In terms of implementing change in a company and the actual carrying through of such change, the company in question must plan ahead as much as possible. Emphasis on strategic management requires a regular reassessment of the company's strategy, corporate culture, evolving structures, coping programs for the possibility of a crisis, plus those for management challenges, the preparation of change scenarios, providing resources for unexpected or unplanned changes, and instructing staff. Involving employees in the process of implementing change in a company is one of the required tools when it comes to ensuring employee job security. Researchers describe employee job insecurity as a source of considerable stress, one that can negatively affect the psychological health of employees, along with their attitude towards their work and, ultimately, their work efficiency [1]. Employee job security itself is defined by said researchers as consisting of certain guarantees regarding one's workplace, which in turn, ensures social and economic security [2]. Researchers [3] distinguish between two dimensions of employee job insecurity from a subjective point of view: 
- cognitive employee job insecurity, which refers to the probability as assessed by the employee themself that they will lose their job in the near future (information assessment);

- emotional employee job insecurity, which refers to the employee's anxiety or fear of losing their job (emotional reaction).

An essential discussion when analyzing this social phenomenon concerns how to motivate and effectively prepare employees for a situation that will involve change and how employees can be involved in change management processes. After a more in-depth discussion of the role of employees in change management within a company, it can be argued that employee participation is key to change management processes. A case study design and mixed research approach were employed. The study was, thus, both qualitative and quantitative. Interviews and questionnaires were used as tools for collecting data from respondents. Mathematical and agent-based modeling was carried out in order to reinforce these methodological positions. Organizations are forced to effectively handle their change management processes in order to gain knowledge that will help them to survive and compete in the current social environment. This aspect covers a wide field of interdisciplinary discourse. However, the direct involvement of employees in change management, i.e., the bottom-up management of the manufacturing sector, is an area that has not been examined in detail. The main problem is that the implementation of any change is mainly considered to be a normative concept that lacks a specific behavioral approach when it comes to realizing the actual implementation of change and its main constructs at the company level.

In noticing this methodological gap, we have formulated a scientific problem that encourages an evaluation of employee involvement in the area of change, ensuring an understanding of the necessity of change and commitment. The main research questions involve the following:

- RQ1: what are the key aspects of employee engagement in the change management processes within the manufacturing sector?

- RQ2: What was the score achieved by the examined enterprise in their employees engagement in the change management processes and how can the results achieved be verified by testing various modeling methods?

The main goal of this paper is to highlight the principal aspects of employee engagement in change management processes and to gain an increased level of understanding in terms of the implementation of change at the organizational level by involving employees.

\section{An Analysis of the Related Literature}

From a methodological point of view, there are two radically different theoretical concepts that have been put forth: the 'prescriptive approach' and the 'emergent approach', both of which underpin strategic management. The implementation of change is closely related to the choice of approach, picking one of the two listed above. The use of the prescriptive approach [4-10] requires a strategy that is less flexible, with human resources being managed from the top and decisions being made at the organizational level. The emergent perspective ([11-18]), on the other hand, means that the change strategy is constantly being developed. According to this perspective, strategic decisions are born gradually and uninterruptedly, and they cannot be combined in one single step into a cohesive, complete corporate strategy. The authors of this paper pointed out that traditional approaches are vs. (versus) new approaches on the analysis of social phenomena. It is only in the last five years that new approaches have started to emerge with the main idea of replacing the dominant change management only on the role description of a leader centered approach to studying, developing, and practicing change management. Furthermore, there is a growing recognition in the field of change management studies that the context of issues has changed, and nowadays, management face new challenges that necessitate changes in the ways the levels of employee involvement and the factors influencing the involvement are utilized (employee change initiatives; employee involvement in change 
related decision-making; employee qualifications; work experience; skills; timely access to information about planned changes and crises; communication and regular feedback; continuous training and development of employees at all levels of change management processes and promotion of teamwork). These factors influence the willingness of employees to participate in change management in the company. The researchers Stacho et al. [18] have developed scientific debates on changes in approach to employee development in organizations on a regional scale and used the terms describing employee improvement interchangeably. They argued that organizations should care about employee improvement and should apply the scientists' recommendations, seek to make use of researchers' insights for the organizations' advance and sustainability, and that society should care about organizations' attention to employee improvement. Our study reflected on a shared vision to promote holistic understanding throughout the change process in a manufacturing company. This paradigm emphasizes supportive processes. According to Alas [19], supportive processes ensure that everything possible can be done in order to help employees to change their commitment to the company, motivating them to forget old habits and to take on new ones, showing them that the risks can be beneficial, and revealing the relationship between the goals of the employees and those of the business. The addition of these two paradigms allows meanings of change management processes in an organization.

The authors of this paper are guided by the emergent perspective. We argue that this theoretical point of view is the best way in which to expand the role of employees who are involved in the change management processes within a company. In addition, it can serve to mitigate negative resistance to new strategy by employees due to a lack of understanding and promote the quick implementation of any new strategy [20].

Based on the theoretical constructs of researchers [4,6-35] who have discussed the arena of change in various organizations, we expanded the base of our research methodology. This methodology includes the following areas of interest: employee change evaluation; the role of different levels of organizational support and change participation; the mediating role of organizational change, along with fairness and commitment to change; change leadership; and engagement and change communication.

First, according to Konrad [25], the statement can be made that an analysis of employee participation in the processes of change reveals three important aspects: (1) the cognitive aspect, which is related to the employee's opinion of the organization, its managers, and its working conditions; (2) the emotional aspect, which is related to how the employee generates these three factors and whether they have a positive or negative influence on the employee's opinion about the organization and its managers; and (3) the behavioral aspect, which is an added value component of an organization, one which consists of self-contained efforts to involve employees in additional work to carry out and consolidate intelligence and energy-donated tasks.

Second, we can state that the emerging approach has been developed by Alas [19] in a survey that was carried out in Estonia and found that the willingness of employees to engage in change is determined by certain indicators: occupational interests, age, education, and the position they occupy at work, along with time worked in the company and their gender; individuals with any professional interest are more involved in the change process. She found that the level of employee involvement depends upon the level of that employee's education and the organization's hierarchy. Employees with a higher level of education and position tend to play a more participatory role in change. Those employees who have been with a company for about four or five years show the highest percentage of adaptability to change as part of the engagement processes. Male employees tend to be more enthusiastic about the processes of change. Bilan et al. (2020) [36] determined the links of gender discrimination with compensation and benefits practices and discussed the main features of assurance of equal rights and their impact on employees' motives that can shift economic results of the enterprises.

Third, we can emphasize that the emerging paradigm has been seen to be valuable by Rylatt [31], who seeks to distinguish between and classify agents for change. The author 
argues that the enthusiasm of agents for change and 'change missionaries' can be attributed to their levels of productivity, with their choice affecting the success of any change. When implementing change, organizations use agents of change who differ in terms of their levels of productivity. High-performance agents for change stand out in terms of their ability to negotiate, to be more open, and to have a more important job description, which is a prerequisite for more meaningful results [31]. We believe that correctly choosing and delegating agents for change has strong benefits and ensures a more successful and easier method of implementation in terms of change within a company.

In addition, we extended the theoretical basis for the analysis of such a social phenomenon that, when based on an emerging perspective, is what was conducted by Cervone [32], who constructed the 'promoting a model of inclusive change' scenario. This model serves to express the idea that change is a natural process, but it also exposes the main problem: stakeholders and employees are not involved in the process of change. According to Cervone [32], changes are not treated as a neutral or negative choice; this is a natural process and one that can begin at any level within the organization. First, the process of promoting change is influenced by the organization's efforts to foster creativity and active participation, and in order to achieve this, the organization's leaders must be able to promote the environment in three ways: ensuring the presence of staff who understand your organization; ensuring the presence of personnel with authorization to operate; and ensuring the employment of staff members who do not hesitate to challenge the status quo or the established order [32]. It can be stated here that this theoretical model describes directions of leadership and identifies specific tasks, taking into account stakeholders and ideas concerning ethical and social responsibility and creating an atmosphere of trust.

Subsequently, we have adapted this theoretical concept for our own case study. In particular, in having to discuss successful change, we are supportive of the development of a wider understanding of leadership, as exemplified by DAC/PAC (leadership = the production of direction/purpose, alignment and commitment). Furthermore, we have expanded this theoretical model under the main concept of successful change and leadership and have classified our research framework with respect to two paradigms:

I. change processes encourage individuals to rethink their personal relationships and compatibility with the organization [9,19-27];

II. the company in question needs a strategy regarding employee involvement in change management $[15,28-49]$. The main link between these two segments can be explained in the argument that organizational change may lead to a change in the relationship between employee and organization, so it is important to highlight this employee involvement in any implementation of change when it comes to group organizers and factor groups, such as in terms of the following:

1. communication (to communicate change outcomes [50]; change triggers interest in organizations [51]; organizations that have properly been able to report the aspects of organizational change to their employees tend to reduce their risk of employee resistance and increase employee commitment to the organization [30]; the challenges that are faced by organizations in managing internal change include their ability to keep employees committed to the change process, with communication within such organizations remaining a key function);

2. involvement by employees in decision-making processes within organizations (the most successful factor in the implementation of change [43,47,52]; employee capacity to adapt and contribute, as well as their willingness [53];

3. this area is highly important when change is actually initiated; leaders and agents for change should find a way to prevent resistance or at least to reduce it (clearly it can be seen that learning and development can be beneficial in this direction) $[31,46,49,54]$.

In order to broaden the methodological basis of our study, we relied on a conceptualization of change management in terms of an employee's performance levels [55], which reveals two directions of organizational response: inertia and flexibility. 
Furthermore, we can emphasize that successful change happens at the bottom and is something that should be engaging people at all levels of the company. Engaged employees are dedicated and loyal to the company. When employees are involved, they are emotionally attached to the vision that the organization possesses. They believe in what they are doing, along with the company's vision, and the direction in which the organization is going [56]. In addition, employee trust and active commitment can be restored and employee motivation can be improved through an employee promotion program and employee involvement in decision-making [57]. Employee involvement will enable the company to ensure the efficient and effective utilization of internal resources for the change process because employees are well aware of the business processes and can offer insightful information into business desires, having realized the principles behind any proposed change. This will ultimately lead to saved time and costs [58] and create new areas of possibility when looking at change from different angles at the same time [59].

Therefore, we have to point out that highlighted segments, groups, and factors regarding employee engagement and involvement in the implementation of change within an organization are manifested in all phases of the change processes: from the preparation for change; during its implementation, and in terms of its institutionalization, control, testing, and producing a summary of the results.

This conceptual perspective has helped us to answer the questions: how can people be encouraged to be responsible? how can we increase change and results by involving employees? how do we see the influence of stakeholders in the change management processes? The key aspect is that significant organizational change cannot be achieved without the cooperation of relevant stakeholders.

\section{Methodology}

Following the emergent approach, an instrumental case study design and a mixed research strategy were employed as the most suitable methodology to achieve answers to the research questions that had been raised for this study. First, we carried out a qualitative study with interviews on the opinions of managers and experts on organizational changes and their attitudes towards employee involvement in this process of change, which was followed by a quantitative method / questionnaire aimed at identifying employees' views and reflections on the processes of change and their experience [44].

A qualitative research strategy using such methods: content analysis of strategic documents of the company and interview) has valuable levels of reflection on the field of change management in companies [60] by assessing the levels of employee involvement in change processes during initiation, planning, implementation, monitoring, and evaluation stages We applied such a qualitative research strategy with the aim of describing the implementation of changes in the company and understanding how employees could be involved during the entire change process, Therefore, we interviewed management figures, as well as experts in change management processes, regarding the envisaged and implemented changes within the organization. Furthermore, we conducted a questionnaire amongst employees of the company in order to understand their role, reflections, and engagement in the change management process. To be able to ascertain employee involvement in change processes, we made use of data triangulation.

This design enabled us to develop certain theoretical insights and helped to test empirically and lead to our methodological paradigm: theoretical matrix.

This study was a mixed research anchored and based on the philosophy of realfield construction and interpretation, which informed the adoption of qualitative and quantitative research strategies. The study adopted the case study design in order to achieve depth in understanding the phenomena at hand.

We used the instrumental case study of a specific area of enterprise on the industrial sector as a fast growing one in Lithuania [61] to understand in depth the phenomenon that is being studied. Specifically, we used an instrumental case study [62] that allowed us to holistically analyze the implementation of change processes and to build up a theoretical 
model of employees engagement in organizational change within the challenging context of Lithuanian industry. Research methodology is based upon naturalistic enquiry and the notion of social constructionism calling for a move 'from empiricism to constructionism and interpretivism' [63]. The case study allows us to see the change management processes as integral to all of the company's activities within its context, which allows us to understand the reasons behind the decisions that are being made and the logic behind the sequence of events. It also allows us to 'feel 'any problems regarding employee engagement in the change processes.

For the instrumental case selection, the process of non-probability purposive sampling was chosen as a sampling strategy. Purposive sampling was applied to find an industrial company that effectively managed strategical changes after an economic crisis period (2008) in such sector and was a leader as a medium-sized manufacturing enterprise; it operates in the industrial region of Lithuania. The company would reflect the three qualitative sampling criteria of his experiences of at least three years. We were looking for companies that have implemented significant changes in their organization over the past three years in response to the 'Lithuanian Progress Strategy 2030'. For this purpose, we employed the qualitative strategy of directory and data sampling: we applied qualitative selection criteria (from the register of the most efficient Lithuanian industrial enterprises in the past three years; this manufacturing company was selected as a leading company in one of the Lithuanian regions and created the most job places in the industrial regions in Lithuania). In line with research ethics, the company was unnamed. During the course of the study, the company employed a total of seventy-eight people. For the purposes of that study, we focused on the critical period for the company (the last three years) when major changes took place in order to manage and reallocate the company's resources.

\subsection{Data Sources}

The empirical part of the study employed primary and secondary data sources (Table 1).

Table 1. The research instrumentation.

\begin{tabular}{ll}
\hline \multicolumn{1}{c}{ Stage of Research } & \multicolumn{1}{c}{ Criteria/Dimensions } \\
\hline & $\begin{array}{l}\text { Changes in the selected organization and the } \\
\text { processes of change implementation are } \\
\text { analyzed: }\end{array}$ \\
$\begin{array}{l}\text { Stage 1 Identification of change } \\
\text { implementation processes in the selected } \\
\text { organization }\end{array}$ & $\begin{array}{l}\text { 1. } \quad \begin{array}{l}\text { Changes in the organization (their types) } \\
\text { and the reasons for them; } \\
\text { The applied model of change } \\
\text { implementation, its main and supporting } \\
\text { elements; }\end{array} \\
\text { Identification of factors determining the } \\
\text { success of change }\end{array}$ \\
\hline
\end{tabular}
of organizational change, taking into account the overcoming of resistance to change through the involvement of employees:

Stage 2 Determining the involvement of employees in the implementation of change

Stage 3 Developing a model for implementing change involving employees
1. Identification and promotion of employee involvement in the implementation of change;

2. Expression of resistance to change in the organization and ways to overcome them.

Development of a model as a tool for organizations to better implement change by involving employees:

1. Systematic analysis of change implementation as a change management stage;

2. Determining the relationship between employee engagement activity and change implementation actions.

Methods
Analysis of scientific literature;

Organization document analysis;

Semi-structured interview; case study;

Analysis of scientific literature;

Semi-structured interview;

Questionnaire; case study

Analysis of scientific literature;

Organization document analysis;

Semi-structured interview; case study. 
Primary sources included a semi-structured directed interview $(N=4)$ with the managers of the company, those who envisioned and implemented changes in the organization and one expert (to deepen the insights gained during the semi-structured interviews with company executives) [64].

Additionally, primary data were also collected using a questionnaire for all employees $(n=78)$.

The study consisted of 31 mixed-type questions-closed, semi-open, and open. All questions were divided into three question blocks. The first was for demographic data, the second was for developing the topic of engagement, and the third was for developing change and the impact of change. The survey was conducted on 21-31 January 2019. The selected company fully met the survey criteria set for the respondents (industrial company, number of employees about 100 employees, at least 10 years of successful experience in the market). The sample of employees was calculated according to Formula (1):

$$
n=\frac{1}{\Delta^{2}+\frac{1}{N}}
$$

where $n$ is the sample size, $\Delta$ is the error size $(0.01-0.04), 1 / N-$ is the size of the $N$-general population. The secondary sources have been included in the systematic literature review, along with websites, statistics, and content analysis of strategic documents. These sources made it possible to develop our theoretical framework, as well as to insert the various criteria and indicators into the analysis.

The four interviews with the owner and managers of various departments in the company were carried out on the company's premises, in a natural working environment, in order to ensure an open atmosphere. All of the interviews were carried out within a month of the launch of the change initiative on a face-to-face basis, with audio being recorded and transcribed. On average, the interviews lasted for about 20-35 min. The interviewee participated in the interview setting and attempted not to influence the opinion of the interviewee in any way. The anonymity of the company and individuals was ensured to further foster openness and trust between the interviewer and interviewee. The interview protocol was developed by following the key dimensions focused on: first, the identification of change processes in an organization; second, reflections on how employees are involved in change processes and how employees are proactive; third, determination of the success of the implementation of the changes, taking into account the resistance of employees and indicators that have been derived from our literature review. Based on these dimensions, the interview was constructed by drawing three scenarios. The aim of the manager interviews was to understand the role that managers were playing in the strategic reorientation of the company, their view on the change processes that were being implemented within the company, to what extent they had involved employees in these processes, and what were the activities they had undertaken and the experiences they had enjoyed during the process of implementing changes to the company.

In order to better contextualize and understand the manager interviews, one expert coach interview was conducted. The expert was a change management consultant with a volume of experience in the field of change management training and consultancy for the private sector in Lithuania. This interview provided important additional information thanks to the expert's professional experience in supporting change management processes in various companies, which allowed us to take distance and contextualize the processes studied in the case study organization.

The secondary data sources have been included in the literature review, as have strategic documents for the company that cover the preceding three-year period.

Based on theoretical insights that have been gleaned from the literature review, as well as from the interview, we were able to develop a questionnaire instrument that was to be administered amongst the company's employees. With the quantitative part of the study, we aimed at understanding as part of the case study's organization the activities, responsibilities, and experiences of employees during the process of undergoing 
the change processes. This instrument was designed with the following blocks: the changes taking place in the organization and employee's reflections; the main and supportive elements during the changes; the factors determining the success of changes and employee's reflections.

The questionnaire also included open answer options while ensuring anonymity through any responses. This version of the questionnaire was used in a pilot study amongst various employees. Thanks to the answers and comments provided during this pilot study, we were able to adjust the questionnaire for the main survey, which was subsequently carried out via electron means-using email and social networks to disseminate it amongst all of the company's employees, with a response rate of $85 \%$.

\subsection{Data Analysis}

In order to be able to establish a systematic methodological position, we used the content analysis method to interpret the interviews, along with documentary and survey data, following the path already trod by other researchers $[65,66]$. After multiple reiterative readings of the interview transcripts, we identified our thematic categories based on selected keywords. Furthermore, we developed sub-categories and checked for overlaps. The coding was carried out on the categories and sub-categories. We identified a number of themes that emerged from the data by following the criteria that had been established by the research dimensions. The open answers in the questionnaire were coded and interpreted using content analysis.

The main findings (taken from the interviews, along with documentary and questionnaire results) formed the basis for making proper use of the key dimensions and being able to generate a theoretical matrix.

Operationalization of the key dimensions was based on five indicators, which were taken from the performance levels of the employees themselves:

1. changes in an organization (in the form of types of change) and the underlying causes;

2. the change implementation strategy as the main idea and supporting elements that are seeking change;

3. identifying those factors that determine the success or failure of change;

4. the expression of resistance to change within the organisation and how this works.

5. identifying and promoting the process of recruitment in terms of new areas of change.

\subsection{Case Study Analysis: The Theoretical Matrix of Change Implementation by Involving Employees}

The instrumental case study being illustrated involves a manufacturing company that, since 1991, has owned an electrical equipment plant in the northern area of Lithuania. At the time of the investigation, the company was seen as one of the leaders in the Baltic region in the area of electrical and automation equipment and had established itself in foreign markets, such as those of Norway, Finland, Denmark, Estonia, Latvia, and France.

This manufacturing company implemented radical change during the period between 2009-2018 (we studied the Strategic Doc 1-Plan). According to the strategy, this company actively engaged employees in change processes at various levels. The company's management body began the change process by clarifying the strategic direction of the company activities.

The company has constantly been adapting to new environmental market demands and has implemented changes that are related to the diversification of products, changing management structures, and changing the orientation of its main activities. As these changes are all interconnected, as a result, a range of other developments also took place from 1991 onwards, which include the introduction of a quality management system, an environmental protection system, and also a change of leadership at the top of the company.

The company gradually increased its production variety while also increasing its production volumes and engineering capacity as the number and variety of clients has increased over time. At the outset, the company specialized in the design and production 
of electric shields, which were being made according to the specific requirements of clients. At the time of the investigation, the company was producing both electrical and automation equipment. The customized design and production of equipment has remained the main feature of the company's products and its main competitive advantage over the years.

The key change in the management structure since 1991 was related to a change in company ownership, as the management body had the vision to begin operating in foreign markets while, on the one hand, also becoming a regional leader and on the other hand, being pressed to do so due to economic conditions in Lithuania at that time (Strategic Doc 2-New Strategy). In 2004, the company's owners sold 25\% of the total number of shares to the Estonian company group and later sold $51 \%$ of the shares. This group also partially owns two companies in Estonia and one in Finland. The main reason to change the company's ownership, as was noted in the media, was caused by the company's aim to ensure production growth and to attract higher levels of investment. Furthermore, the goal was to obtain the experience, reputation, and image of partners, which would allow it to better compete and to establish itself on the market. This change, on the one hand, influenced its freedom to make strategic decisions while, on the other hand, ensured financial stability and opportunities in terms of expanding production into new markets and expanding its more trustworthy network of customers.

Finally, changes in the orientation of the company's activities are related to the diversification of its products and services. From the start, the company would design and manufacture a narrow range of equipment. Over time, it has diversified its production into applications for various sectors, including both design and production, as well as the provision of services in terms of implementing engineering projects for various industries, which included energy, electronics, construction, oil extraction, renewable systems, IT solutions, and maritime, and this lasted until 2010. However, the internal market in Lithuania was very small while the levels of competition were high. The combination of production and the provision of services was becoming paradoxical as they were competing with their customers who were buying their products on the services front. This went against the values of the company, so in 2018, it was decided to halt the provision of services, even though this was a really profitable segment of its products. At the same time, the shareholders decided to expand production into foreign markets, which meant that the company had to reorientate itself to face in one specific direction: to be a manufacturer of electronic equipment. This radical change to streamline its main activity areas took place in 2011-2018 with the aim of completely halting service provision in 2018, and it is this process of change that is the focus of our investigation.

To resume, to be able to carry out such an analysis as that involved in our fieldwork, we constructed a theoretical matrix of change implementation within the company, seeking to involve employees more effectively in change processes. Figure 1 shows the structural areas of the theoretical matrix.

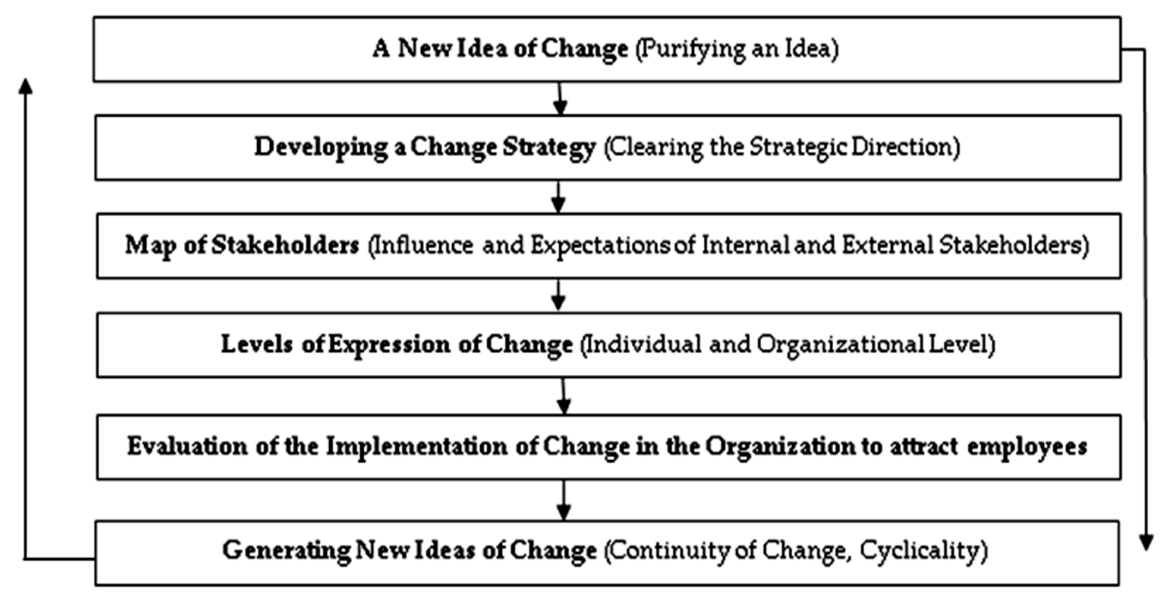

Figure 1. The theoretical matrix: 'implementing change in a company by involving employees'. 
As shown in Figure 1, it should be noted that this matrix is not static. It acts as a cycle: starting on the first stage (a refinement of the ideas behind any change) it proceeds onto subsequent stages until it reaches the sixth and final stage before starting again with the new idea being further purified. This matrix may assist the management body, along with agents of change and practitioners of change, as a theoretical paradigm to prepare any future change strategy; it would be highly useful to anyone who is seeking to implement change in an enterprise by involving employees effectively in any change processes; in addition, it can be used in the discussion about good practical managerial examples.

\section{Modeling the Implementation of Any Change}

In arguing about the main idea regarding change implementation in a company, it can be noted that any company management figures need to consider several implementation options before embarking upon any change. When one factor may have several different values, the simplest method when analyzing potential outcomes is a 'what-if' analysis. However, this does not apply to organizational change, where a good many factors acquire permanent values. For this reason, we have applied mathematical and agent-based modeling to this process. These modeling methods make it possible to observe and study processes that are difficult to model when using other modeling tools [67]. The agent model [68] consists of many interacting agents: employees, departments, organizations, environments, etc. To be able to implement the agent-based models, we need to know the characteristics of the agents, their attitudes, and the real life rules behind their actions and interactions. We obtained the necessary information by conducting an interview and a questionnaire survey.

This section of the paper consists of two subsections. The first subsection provides a mathematical modeling of employee attitudes and attitudinal changes over time. The second section presents the agent-based modeling for the entire company, distinguishing the three segments of human resources in the company (leader, staff-manager, employee) and analyzing how they affect change.

\subsection{Mathematical Modeling}

As mentioned above, in seeking to verify components of the theoretical matrix: 'implementing change in an enterprise involving employees', we started from the point of mathematical modeling. For this study, the five following aspects were assumed:

1. the employee's confidence in any changes is measured in terms of scores that are assessed during the interview [0,100] and consists of two parts: (a) the aggregated satisfaction of employees with the current situation and $(b)$ expectations about a better future;

2. the duration of the applied changes is a period of 3 years;

3. the levels of satisfaction in the current situation at the starting point of the process of those changes being implemented scores about 75 points of a maximum possible 100 points;

4. the downward slide in terms of satisfaction reaches its greatest extent after a period of one year, and the maximum fall is about 30 score points;

5. the confidence levels in and positive expectations changes appear after about 1.5 or 2 years.

A negative attitude towards the changes and a positive expectation of new performance levels were modeled by making use of the functions:

$$
u=k t^{\alpha-1}\left(t_{0}-t\right)^{\beta-1}
$$

This can be referred to as a utility function. It is used for distributions in probability theory for the density functions of asymmetric processes (Figure 2). 


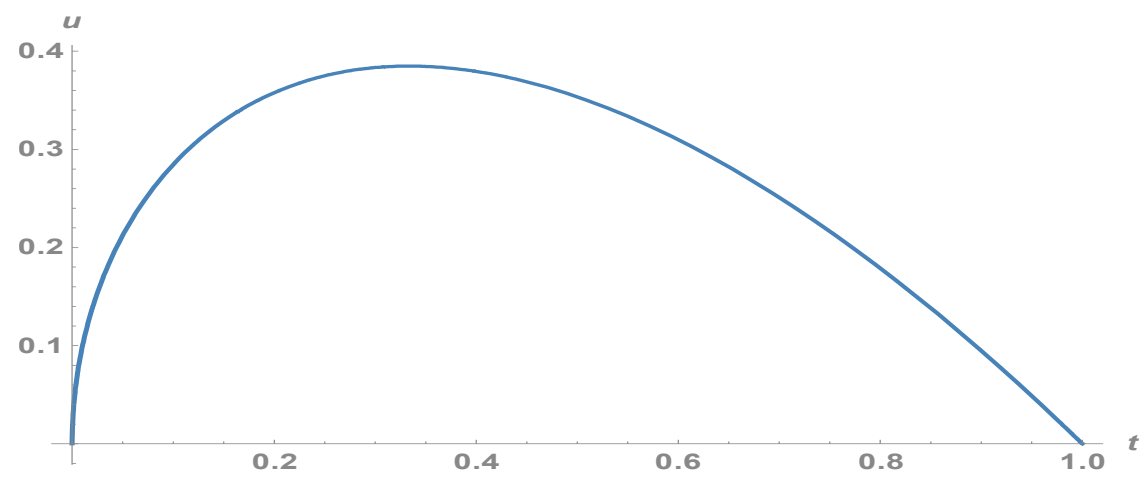

Figure 2. Asymmetric function $u$ when $k=t_{0}=1$ and shape parameters $\alpha=1.5, \beta=2$.

The parameters $\alpha$ and $\beta$ are referred to as the shape parameters. They control the asymmetry of the function plot. It is possible to find these by means of calculus-related methods so that the minimum point of the function $u$ is as follows:

$$
t=t_{\min }=t_{0} \frac{\alpha-1}{\alpha+\beta-2}
$$

and the minimum of the function $u$ equals:

$$
u_{\min }=u\left(t_{\min }\right)=k\left(t_{0} \frac{\alpha-1}{\alpha+\beta-2}\right)^{\alpha-1}\left(t_{0} \frac{\beta-1}{\alpha+\beta-2}\right)^{\beta-1}
$$

Taking into account the assumptions about a negative attitude towards the changes, and from Equations (1) and (2), it follows that $\alpha=1.2, \beta=1.5, t_{0}=3.5, k=-20$ (Figure 3):

$$
u_{n}=-20 t^{0.2}(3.5-t)^{0.5}
$$

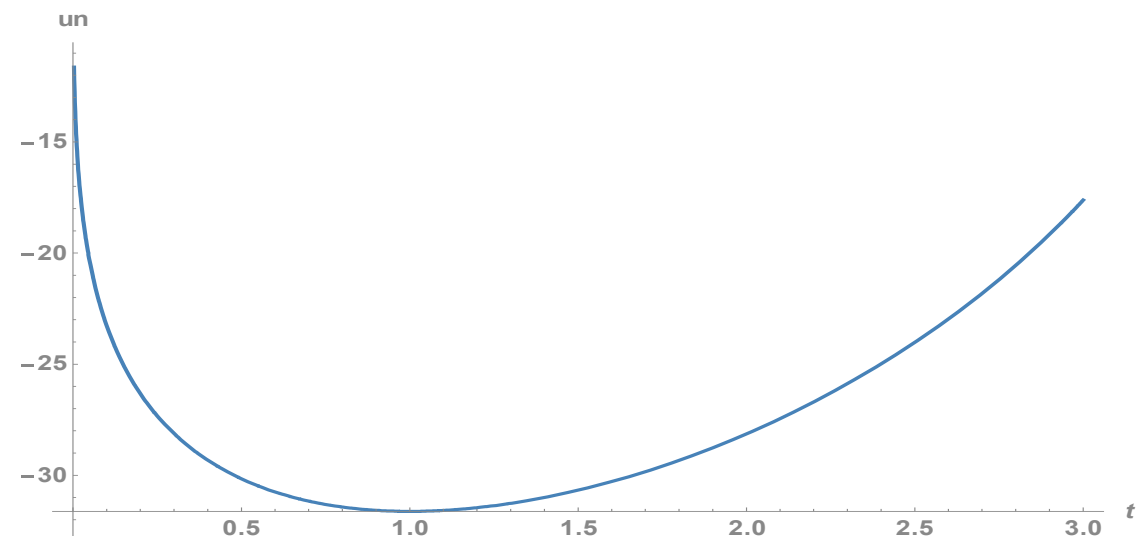

Figure 3. A negative utility function.

It can be seen that a negative attitude is absent at the time moment $t=0$, and then after one year $(t=1)$, it reaches a reading of about 30 points. It corresponds to the point of acceptance of any changes. Then, the negative attitude begins to vanish. Nevertheless, this does not reach zero as there will always be a certain proportion of dissatisfied people who remain. It should be pointed out that $u_{n}(0)=0$, i.e., the function is relative to the confidence levels at the start time $t=0$.

Similarly, when taking into account assumptions about positive beliefs in the future, the utility function can be written (Figure 4) in the following equation:

$$
u_{p}=0.5 t^{0.5}(3.5-t)^{5}
$$




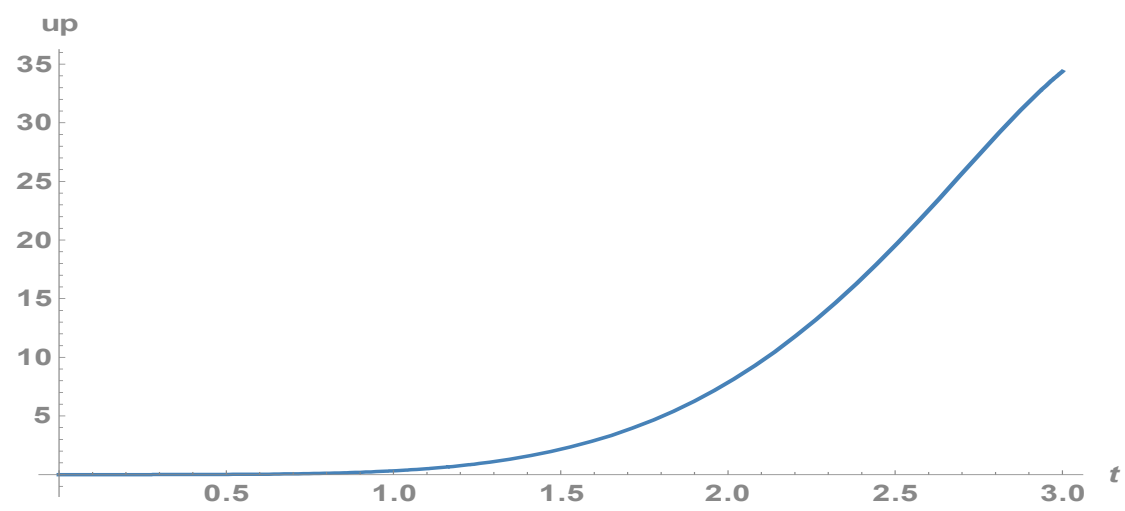

Figure 4. A positive utility function.

It can be seen from Figure 4 that significant trust in a positive future outcome of any changes appears after about 2 years and then increases in terms of score up to 35 points. Trust increases rapidly until $t=2.5$ years and then, this also continues to increase, albeit with a declining rate of increase. It should be pointed out that $u_{p}(0)=0$, i.e., this function is also relative to the levels of confidence at the start time $t=0$.

When putting together scores regarding positive expectations of the future, taking note of the negative utility function regarding current changes, and also taking into account the assumption about the employee satisfaction with their jobs at the start time $t=0$, we get the change function and its curve (Figure 5):

$$
u=u_{p}+u_{n}+75=75+0.5 t^{0.5}(3.5-t)^{5}-20 t^{0.2}(3.5-t)^{0.5}
$$

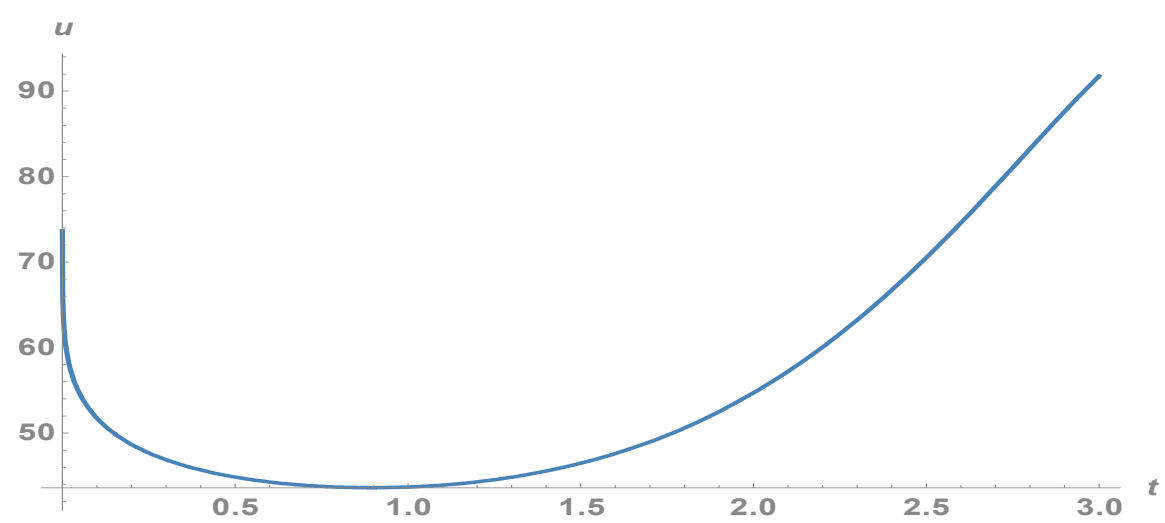

Figure 5. The change curves.

As can be seen in Figure 5, the curve highlights a good many of the more typical features of the change curve: awareness, acceptance, testing, a search for meaning, and integration.

The derived curve is based on assumptions about the entire company. However, the company consists of employees, each with their own opinion and attitude. Therefore, each individual has their own utility function, and these functions can differ significantly from person to person.

We evaluated such trends and extended the analysis by applying an additional layer of modeling (agent-based) in seeking to develop randomized utility functions for different groups of individuals and to be able to investigate the change process using the agentbased model.

There were various findings regarding the mathematical modeling: the process of change within the company was described through the use of several assumptions and by two components and their utility functions: a negative attitude to the changes and positive 
expectations of the new areas of performance. The resulting change curve contains the basic features of the development of any changes.

\subsection{Agent-Based Modeling}

Agent-based modeling was applied in terms of organizational change management and change implementation in the company. The architecture of the agent-based model consists of three human resources segments (leader, manager, employee), all of whom serve to implement change within an organization, and the performance of those three segments affects any changes that may be made.

The agent-based model simulates a single agent of the leader type, along with three agents of the manager type and 100 agents of the employee type. The main properties for each of the employees include motivation, initiative, psychological resistance to change, and conservatism, which remains constant for each person but differs between individuals.

It is assumed that initial resistance to any changes is low and is distributed across the interval [0; 1], according to the beta distribution method (Figure 6), but that it changes over simulation time. The maximum value of the curve is about 0.3 , which means that the majority of employees have a resistance of 0.3 , i.e., weak. The maximum level of resistance 1 has almost no takers at all. The initial resistance of each person is randomly generated according to this distribution law, which is given in Figure 6.

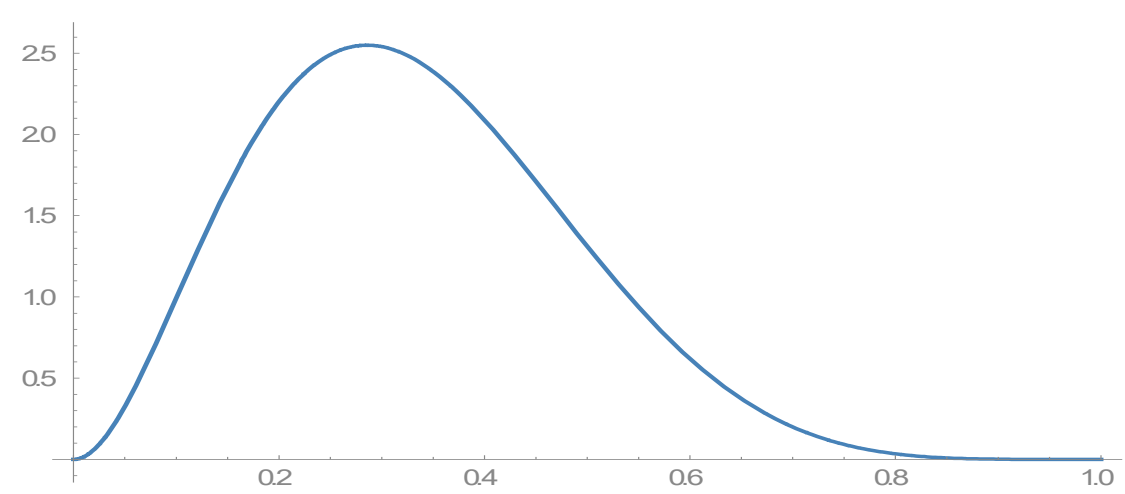

Figure 6. The initial distribution $\mathrm{f}_{(3,6)}(\mathrm{x})$ of resistance to changes.

Resistance is a variable feature, one that changes over the total simulation time. Initiative is a computable property that depends upon conservatism and resistance to changes. For instance, it is assumed that the employee has a leaning towards conservatism of $<30 \%$ and a resistance to changes of $<30 \%$.

Conservatism is also a random value, one that is distributed in the interval $[0 ; 1]$ according to the beta distribution $\mathrm{f}_{(6,3)}(\mathrm{x})$ (Figure 7 ). It does not change over the course of the total simulation time.

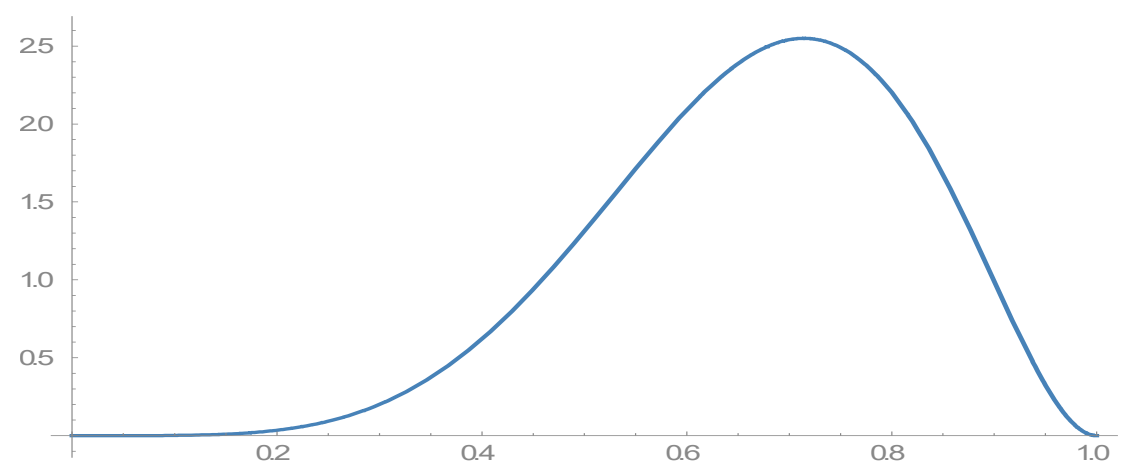

Figure 7. The distribution $\mathrm{f}_{(6,3)}(\mathrm{x})$ for employees. 
At the beginning of the simulation, in other words, its first stage, the management body informs its employees about the impending changes, which are modeled by sending messages to other agents. This communication message decreases psychological resistance according to the following equation:

$$
\text { resistance }=\text { resistance } \cdot(1-\text { message }) \text {. }
$$

The message is the intensity of the communication, taking values from the interval $[0 ; 1]$. Very intensive communication is modeled with a message that is close to 1 and, in the case of the absence of any communication message $=0$. Therefore, the factor ( 1 message) decreases individual resistance if the message is not and increases motivation.

Later in stage II, along with the implementation of changes, it appears that the expectations of some people are not met, and this element of surprise is modeled by increasing resistance, according to empirical relationship:

$$
\text { resistance }=g(\text { conservatism, } \Delta s, t, \text { resistance })
$$

Here, $\Delta s$ is used to refer to the change in a person's status within the organization, while ' $t$ ' is time. The function $g$ () serves to increase the function with respect to $\Delta s$, i.e., regarding rapid changes in a person's status serving to increase their psychological resistance to any changes. The variable 'resistance' refers to a person's resistance level one-time step ago, with a higher level of 'resistance' corresponding to a higher level of resistance in the new time moment, and vice versa. Conservatism is a constant for each person, with higher levels of conservatism corresponding to the higher values of resistance.

This modeling stage corresponds to the decreasing section of the motivation curve, which is shown in Figure 8.

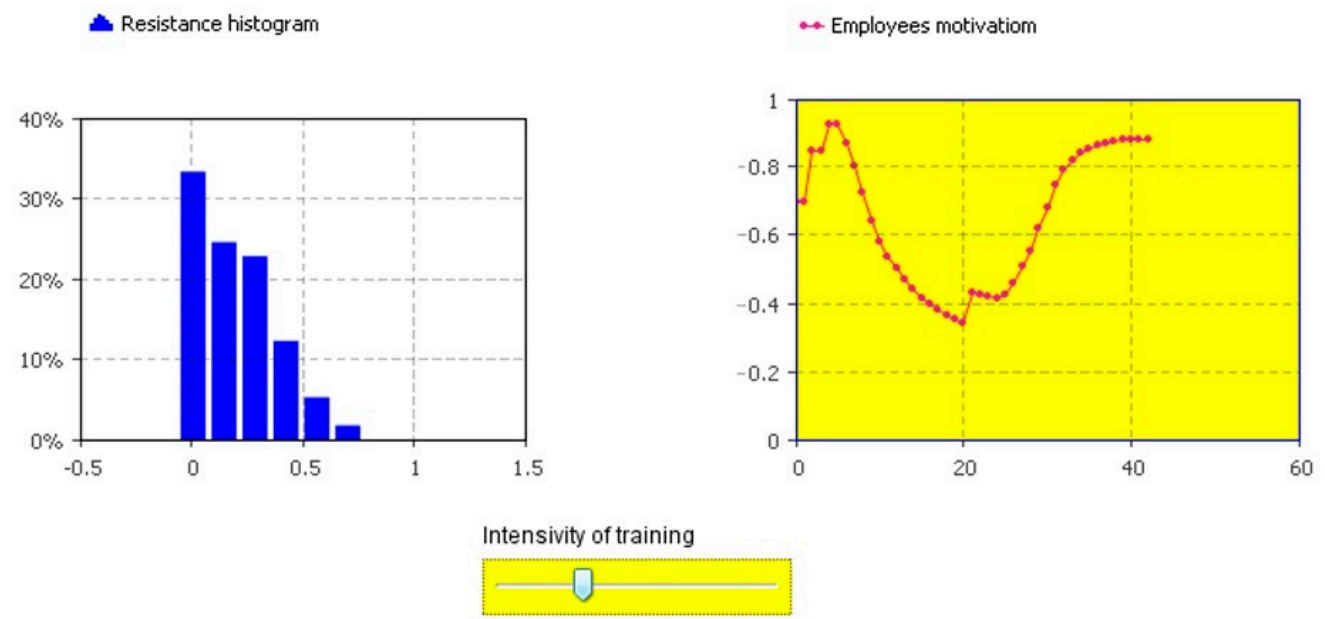

Figure 8. The modeling of organizational change over time.

Managers are trying to overcome the decrease of motivation by means of issuing awards for initiative, which serve to decrease the amount of resistance according to the precise relationship:

$$
\text { resistance }=(1-k) \text { resistance }
$$

The coefficient ' $k$ ' belongs to the interval $[0 ; 1]$ and is chosen empirically. These and other measures end resistance, with most employees entering stage III, which corresponds to an evident increase in motivation.

To be able to continue to increase motivation in employees, management figures initiate training amongst their personal, and this is modeled in stage IV. 


\section{Discussion}

In order to maintain a competitive position, every company inevitably faces changes that are either larger or smaller and for a variety of reasons (such as globalization, technological change, worker mobility, etc.). It should also be emphasized that a company cannot exist without employees whose performance is directly affected by a sense of security at work. Therefore, it is necessary to ensure employee job security, as well as the physical safety of those employees, in order that any necessary changes can be properly and successfully implemented. The available scientific literature examines various aspects of employee job security [53-60], but those aspects that are emphasized most frequently are as follows: assuring a stable income, employment preservation, and the continuous acquisition of necessary job skills, etc. Therefore, one of the measures that could be implemented in order to ensure a sense of security for employees when making changes in the company is to involve them in the process of implementing any such changes.

However, involving employees in the implementation of the process of change is not quite as simple as it may sound, as this is an area that can be influenced by a great many factors. One of those factors involves approaches towards working, which can differ across generations. Researchers [61-63] have distinguished methods to be able to show that different generations can have different approaches to work, along with their key characteristics. Other researchers emphasize the fact that high employee engagement is directly correlated with a low company employee turnover rate [69-80]. In 2017, the personnel consulting company, Mercer, conducted a survey in which it found that the time at which employees felt most motivated to become involved in the implementation of changes in the company was right after they are first employed, while after one year of employment their levels of motivation dropped to $75 \%$ on average.

Therefore, it can be seen that this particular topic is one that has very widely been analyzed in the available scientific literature. The authors of this particular article plan to apply their research in the future to various sectors.

\section{Conclusions}

This study examines the implementation of changes in the company from a systematic point of view, focusing on employees' involvement in change processes effectively. The methodological novelty of the research is related to the applied emergent approach in the development of qualitative research methodology, which is based on the mixed methods research design with the purpose of complementarity. It can be argued that this theoretical point of view is the best way to expand the role of employees involved in the change management processes in a company. In addition, it can mitigate the employees' negative resistance to new changes due to lack of understanding and promote the quick implementation of new change strategy.

The theoretical matrix of change implementation in the company has been developed. The components of the matrix connecting six dimensions was highlighted: a new idea of change (purifying an idea); developing a strategy of change (clearing the strategic direction); to draw a map of stakeholders (influence and expectations of internal and external stakeholders); to identify main levels of expression of change (three levels: individual, organisational, and input of stakeholders); evaluation of the implementation of change in the company, seeking to attract employees; and generating new ideas of change in the company (continuity of changes, processes, and cyclicality). The matrix is based on a systematic approach, the categorization of elements and structural analysis, and aims to emphasise cyclicality, i.e., a continuous process of change implementation, which can lead to several changes in parallel or gradually - after the end of one change, another. Every dimension was scrutinised, highlighting its principal components that have an impact on change implementation in a company, and modeling method (mathematical and agent-based) selection was justified.

To sum up, the matrix was verified using mathematical and agent-based modeling where the main change agents and expression of its positions were highlighted, and 
the influence of human resources on change was substantiated. The implementation of change strategy involves three key interrelated stages. At organisational level, the implementation of change involves preparation and key actions. The implementation of 'hard factors' consolidates change and prepares for new changes. At the individual level, the psychological prism is looked at and the following stages are distinguished: primary vision presentation; supportive actions, i.e., implementation of 'soft factors', institutionalisation of new habits, also emphasises the role of stakeholders in implementing change, which influences decisions at all stages of change implementation.

The results obtained by mathematical modeling show the different attitude of employees to change over time (the duration of the changes no longer than 3 years was most effective; employee satisfaction of the current situation at the beginning of the change was 75 points/a maximum of 100 points; satisfaction with the changes the employees reached and saw its maximum size after 1 year, and the maximum change was about 30 points; the trust in the company change strategy and positive expectations appeared only after 1.5 or 2 years); as well, agent-based results note the modeling of the whole company, distinguish human resource segments (leader, manager, employee) in the company, and analyze how they affect change (react differently; the main characteristics are motivation, initiative, psychological resistance to change).

Overall, our findings not only provide a broader understanding of change management but also offer companies recommendations on how to effectively engage employees. The theoretical contribution of the paper demonstrates construction of methodology guided by the emergent perspective and new theoretical insights on professional discourse. Practical input shows that employee involvement in change processes is directly related to the speed of strategic change in the company.

Author Contributions: Conceptualisation, A.V. and I.M.-K.; methodology, A.V. and R.Č.; software, R.Č.; validation, A.V. and I.M.-K.; formal analysis, R.Č.; investigation, A.V.; resources, R.Č. and I.M.K.; writing—original draft preparation, A.V.; writing—review and editing, I.M.-K.; visualisation, R.Č.; supervision, I.M.-K. All authors have read and agreed to the published version of the manuscript.

Funding: This research received no external funding.

Institutional Review Board Statement: Not applicable.

Informed Consent Statement: Not applicable.

Data Availability Statement: The data of this study is available from the authors upon request.

Conflicts of Interest: The authors declare no conflict of interest.

\section{References}

1. László, K.D.; Pikhart, H.; Kopp, M.S.; Bobak, M.; Pajak, A.; Malyutina, S.; Salavecz, G.; Marmot, M. Job insecurity and health: A study of 16 European countries. Soc. Sci. Med. 2010, 70, 867-874. [CrossRef] [PubMed]

2. Sverke, M.; De Witte, H.; Näswall, K.; Hellgren, J. Editorial introduction. Econ. Ind. Democr. 2010, 31, 175-178. [CrossRef]

3. Herzog-Stein, A.; Zapf, I. Navigating the Great Recession. ILR Rev. 2014, 67, 891-925. [CrossRef]

4. Ragsdell, G. Engineering a paradigm shift? J. Organ. Chang. Manag. 2000, 13, 104-120. [CrossRef]

5. Burnes, B. Kurt Lewin and the Planned Approach to Change: A Re-appraisal. J. Manag. Stud. 2004, 41, 977-1002. [CrossRef]

6. Todnem, A.C.; Arnesen, L.; Gaasø, R. 4D Seismic and Through Tubing Drilling and Completion Wells Extend Life on the Gullfaks Field. In Proceedings of the SPE/IADC Drilling Conference, Amsterdam, The Netherlands, 23-25 February 2005; OnePetro: Richardson, TX, USA, 2005.

7. Maurer, T.J.; Lippstreu, M.; Judge, T.A. Structural model of employee involvement in skill development activity: The role of individual differences. J. Vocat. Behav. 2008, 72, 336-350. [CrossRef]

8. Kotter, J.P.; Schlesinger, L. Choosing strategies for change. Harv. Bus. Rev. 2008, 86, 130-139.

9. Graetz, F.; Smith, A.C.T. Managing Organizational Change: A Philosophies of Change Approach. J. Chang. Manag. 2010, 10, 135-154. [CrossRef]

10. Fugate, M.; Prussia, G.E.; Kinicki, A.J. Managing Employee Withdrawal During Organizational Change. J. Manag. 2012, 38, 890-914. [CrossRef]

11. Vasiliauskas, A. Strateginiai pokyèiai ir savivada organizacijoje. Pinigu Stud. 2014, 1, $23-35$. 
12. Vienažindienè, M.; Čiarnienè, R. The changes of public organizations' human resources management: Theoretical aspect. Econ. Manag. 2007, 12, 660-668.

13. Burtonshow-Gunn, S.A. Svarbiausios Vadybos Priemonès: Metodai, Modeliai, Pastabos Vadovams ir Konsultantams; Verslo žinios UAB: Vilnius, Lithuania, 2009.

14. Shamir, E.R.; Ewald, A.J. Three-dimensional organotypic culture: Experimental models of mammalian biology and disease. Nat. Rev. Mol. Cell Biol. 2014, 15, 647-664. [CrossRef]

15. Bhatt, P.R.; Bhatt, R.R. Managing Change at Muhibbah Engineering (M) Bhd. South Asian J. Bus. Manag. Cases 2017, 6, 12-25. [CrossRef]

16. Wiesner, R.; Chadee, D.; Best, P. Managing Change Toward Environmental Sustainability: A Conceptual Model in Small and Medium Enterprises. Organ. Environ. 2018, 31, 152-177. [CrossRef]

17. Thomas, B.; Tendai, K.; Zororo, M.; Obert, S. Employee Involvement in Change Management in Organisations: A Case of the Zimbabwe Electricity Transmission and Distribution Company (ZETDC). IOSR J. Econ. Financ. 2019, 10, 14-27. [CrossRef]

18. Stacho, Z.; Stachová, K.; Raišienè, A.G. Change in approach to employee development in organizations on a regional scale. J. Int. Stud. 2019, 12, 299-308. [CrossRef]

19. Alas, R. Employees' willingness to participate in implementation of organizational change. Organ. Vadyb. Sist. Tyrim. 2008, 46, $7-15$.

20. Yi, Y.; Gu, M.; Wei, Z. Bottom-up learning, strategic flexibility and strategic change. J. Organ. Chang. Manag. 2017, 30, 161-183. [CrossRef]

21. Rofcanin, Y.; Bakker, A.B.; Berber, A.; Gölgeci, I.; Las Heras, M. Relational job crafting: Exploring the role of employee motives with a weekly diary study. Hum. Relat. 2019, 72, 859-886. [CrossRef]

22. Cheng, J.-C.; Yang, Y.O. Hotel employee job crafting, burnout, and satisfaction: The moderating role of perceived organizational support. Int. J. Hosp. Manag. 2018, 72, 78-85. [CrossRef]

23. Afsar, B.; Masood, M.; Umrani, W.A. The role of job crafting and knowledge sharing on the effect of transformational leadership on innovative work behavior. Pers. Rev. 2019, 48, 1186-1208. [CrossRef]

24. Bellou, V.; Chatzinikou, I. Preventing employee burnout during episodic organizational changes. J. Organ. Chang. Manag. 2015, 28, 673-688. [CrossRef]

25. Caulfield, J.L.; Senger, A. Perception is reality: Change leadership and work engagement. Leadersh. Organ. Dev. J. 2017, 38, 927-945. [CrossRef]

26. Soenen, G.; Melkonian, T. Fairness and commitment to change in M \& As: The mediating role of organizational identification. Eur. Manag. J. 2017, 35, 486-492. [CrossRef]

27. Zappalà, S.; Toscano, F.; Licciardello, S. Towards Sustainable Organizations: Supervisor Support, Commitment to Change and the Mediating Role of Organizational Identification. Sustainability 2019, 11, 805. [CrossRef]

28. Konrad, A.M. Engaging employees of personal engagement and disengagement at work. Ivey Bus. J. 2006. Available online: https://www.scirp.org/(S(i43dyn45teexjx455qlt3d2q))/reference/ReferencesPapers.aspx?ReferenceID=1857809 (accessed on 25 July 2021).

29. Alas, R.; Sun, W.; Gao, J. The implementation of organizational changes during the transition in China and Estonia. Balt. J. Manag. 2012, 7, 86-102. [CrossRef]

30. Kool, M.; van Dierendonck, D. Servant leadership and commitment to change, the mediating role of justice and optimism. J. Organ. Chang. Manag. 2012, 25, 422-433. [CrossRef]

31. Rylatt, A. Three Qualities of Highly Successful Change Agents. TD Mag. 2013, 67, 72-74.

32. Cervone, H.F. Organizational change models and digital library projects. OCLC Syst. Serv. Int. Digit. Libr. Perspect. 2013, 29, 61-64. [CrossRef]

33. Swarnalatha, C.; Prasanna, T. Employee engagement and performance excellence. Int. J. Manag. 2013, 4, $212-220$.

34. Fuchs, S.; Prouska, R. Creating Positive Employee Change Evaluation: The Role of Different Levels of Organizational Support and Change Participation. J. Chang. Manag. 2014, 14, 361-383. [CrossRef]

35. Al-Haddad, S.; Kotnour, T. Integrating the organizational change literature: A model for successful change. J. Organ. Chang. Manag. 2015, 28, 234-262. [CrossRef]

36. Bilan, Y.; Mishchuk, H.; Samoliuk, N.; Mishchuk, V. Gender discrimination and its links with compensations and benefits practices in enterprises. Entrep. Bus. Econ. Rev. 2020, 8, 189-204. [CrossRef]

37. Fedor, D.B.; Caldwell, S.; Herold, D.M. The effects of organizational changes on employee commitment: A multilevel investigation. Pers. Psychol. 2006, 59, 1-29. [CrossRef]

38. Barnard, M.; Stoll, N. Centre for Understanding Behaviour Change: Short Policy Report. Organ. Chang. Manag. A Rapid Lit. Rev. 2010, 10. Available online: https://pdf4pro.com/view/centre-for-understanding-behaviour-change-31a805.html (accessed on 25 July 2021).

39. Anderson, D.L. Organization Development: The Process of Leading Organizational Change; SAGE Publ. Inc: Thousand Oaks, CA, USA; London, UK; New Delhi, India; Singapore, 2010.

40. Edmonds, J. Managing successful change. Ind. Commer. Train. 2011, 43, 349-353. [CrossRef]

41. Pieterse, J.H.; Caniëls, M.C.J.; Homan, T. Professional discourses and resistance to change. J. Organ. Chang. Manag. 2012, 25, 798-818. [CrossRef] 
42. Mishra, K.; Boynton, L.; Mishra, A. Driving Employee Engagement. Int. J. Bus. Commun. 2014, 51, 183-202. [CrossRef]

43. Stavros, D.; Nikolaos, B.; George, A.; Apostolos, V. Organizational Change Management: Delineating Employee Reaction to Change in SMEs Located in Magnesia. Acad. J. Interdiscip Stud. 2016, 5, 309. [CrossRef]

44. Stouten, J.; Rousseau, D.M.; De Cremer, D. Successful Organizational Change: Integrating the Management Practice and Scholarly Literatures. Acad. Manag. Ann. 2018, 12, 752-788. [CrossRef]

45. Wanberg, C.R.; Banas, J.T. Predictors and outcomes of openness to changes in a reorganizing workplace. J. Appl. Psychol. 2000, 85, 132-142. [CrossRef]

46. Cohen, A. Dynamics between Occupational and Organizational Commitment in the Context of Flexible Labor Markets: A Review of the Literature and Suggestions for a Future Research Agenda; ITB-Forschungsberichte: Bremen, Germany, 2007.

47. Blanchard, K. Mastering the Art of Change. Ken Blanchard Offers Some Strategies for Successfully Leading Change. Train. J. 2010, 44-48. Available online: https:/ / studylib.net/doc/8649945/mastering-the-art-of-change (accessed on 25 July 2021).

48. Hurn, B.J. Management of change in a multinational company. Ind. Commer. Train. 2012, 44, 41-46. [CrossRef]

49. Sonenshein, S.; Dholakia, U. Explaining Employee Engagement with Strategic Change Implementation: A Meaning-Making Approach. Organ. Sci. 2012, 23, 1-23. [CrossRef]

50. Lewis, L.K. Organizational Change: Creating Change THROUGH Strategic Communication; West Sussex John Wiley Sons Ltd.: Chichester, UK, 2011.

51. Yolanda Jorritsma, P.; Wilderom, C. Failed culture change aimed at more service provision: A test of three agentic factors. J. Organ. Chang. Manag. 2012, 25, 364-391. [CrossRef]

52. Burnes, B. Managing Change: A Strategic Approach to Organisational Dynamics, 3rd ed.; Harlow Pearson Educ. Ltd.: Edinburgh Gate, UK, 2000.

53. Appelbaum, S.H.; Habashy, S.; Malo, J.; Shafiq, H. Back to the future: Revisiting Kotter's 1996 change model. J. Manag. Dev. 2012, 31, 764-782. [CrossRef]

54. Sidorko, P.E. Transforming library and higher education support services: Can change models help? Libr. Manag. 2008, 29, 307-318. [CrossRef]

55. Njuguna, E.N.; Muathe, S.M.A. Critical review of literature on change management on employee's performance. Int. J. Res. Soc. Sci. 2016, 6, 9-22.

56. Torben, R. Real Change Management Happens at the Bottom. 2013. Available online: https://www.torbenrick.eu/blog/changemanagement/real-change-happens-at-the-bottom/ (accessed on 25 July 2021).

57. Osborne, S.; Hammoud, M.S. Effective Employee Engagement in the Workplace. Int. J. Appl. Manag. Technol. 2017, 16, 4. [CrossRef]

58. Mulholland, B. 8 Critical Change Management Models to Evolve and Survive, 2017. Available online: https / /www.process.st/ change-management-models / (accessed on 23 April 2020).

59. Maes, G.; Van Hootegem, G. A systems model of organizational change. J. Organ. Chang. Manag. 2019, 32, 725-738. [CrossRef]

60. Eriksson, P.; Kovalainen, A. Qualitative Methods in Business Research; SAGE Publ. Ltd.: Thousand Oaks, CA, USA, 2016.

61. Yin, R.K. Case Study Methods. In APA Handbook of Research Methods in Psychology, Volume 2: Research Designs: Quantitative, Qualitative, Neuropsychological, and Biological; American Psychological Association: Washington, DC, USA, 2012 ; pp. 141-155.

62. Baxter, P.; Jack, S. Qualitative Case Study Methodology: Study Design and Implementation for Novice Researchers. Dalt. Trans. 2008, 13, 544-559. [CrossRef]

63. Kenneth, J. Gergen Social Construction: From "What is" to "What Could Be.". In An Invitation to Social Construction; SAGE Publications Ltd.: London, UK, 2015; pp. 1-33.

64. Seidman, I. Interviewing as Qualitative Research-A Guide for Researchers in Education and the Social Sciences; Teachers College Press: New York, NY, USA, 2006.

65. Mayring, P. Qualitative Content Analysis. Theoretical Background and Procedures. Examples of Methodology and Methods; Springer: New York, NY, USA, 2015.

66. Pietila, A.; Kallio, H.; Johnson, M.; Kangasniemi, M. Systematic methodological review: Developing a framework for a qualitative semi-structured interview guide. Lead. Glob. Nurs. Res. 2016, 72, 2954-2965.

67. Rand, W.; Rust, R.T. Agent-based modeling in marketing: Guidelines for rigor. Int. J. Res. Mark. 2011, 28, 181-193. [CrossRef]

68. Mobus, G.E.; Kalton, M.C. Principles of Systems Science; Springer: New York, NY, USA, 2015.

69. Böckerman, P.; Ilmakunnas, P.; Johansson, E. Job security and employee well-being: Evidence from matched survey and register data. Labour Econ. 2011, 18, 547-554. [CrossRef]

70. Loi, R.; Ngo, H.-Y.; Zhang, L.; Lau, V.P. The interaction between leader-member exchange and perceived job security in predicting employee altruism and work performance. J. Occup. Organ. Psychol. 2011, 84, 669-685. [CrossRef]

71. Hur, H.; Perry, J.L. Job Security Rule Changes and Employee Organizational Commitment. Rev. Public Pers. Adm. 2020, 40, 641-668. [CrossRef]

72. Preuss, G.A.; Lautsch, B.A. The Effect of Formal Versus Informal Job Security on Employee Involvement Programs. Relat. Ind. 2003, 57, 517-541. [CrossRef]

73. Newman, A.; Cooper, B.; Holland, P.; Miao, Q.; Teicher, J. How do industrial relations climate and union instrumentality enhance employee performance? The mediating effects of perceived job security and trust in management. Hum. Resour. Manag. 2019, 58, 35-44. [CrossRef] 
74. Lu, C.; Du, D.; Xu, X.; Zhang, R. Revisiting the relationship between job demands and job performance: The effects of job security and traditionality. J. Occup. Organ. Psychol. 2017, 90, 28-50. [CrossRef]

75. Vijayan, M. Impact of Job Stress on Employees' Job Performance in Aavin, Coimbatore. J. Organ. Hum. Behav. 2017, 6, 21-29.

76. Shoss, M.K.; Brummel, B.J.; Probst, T.M.; Jiang, L. The Joint Importance of Secure and Satisfying Work: Insights from Three Studies. J. Bus. Psychol. 2020, 35, 297-316. [CrossRef]

77. Graeme Codrington Detailed Introduction to Generational Theory. Available online: https://docplayer.net/65301375-Detailedintroduction-to-generational-theory-in-asia.html (accessed on 21 March 2021).

78. McCrindle, M. The ABC of XYZ: Understanding of Global Generations; University of New South Wales Press: Randwick, Australia, 2014.

79. Flagler, W.; Thompson, T. 21st Century Skills: Bridging the Four Generations in Today's Workforce; Cannexus: Ottawa, ON, Canada, 2014. Available online: http:/ / cannexus.ca/wp-content/uploads/2014/04/21st-Century-Skills-Bridhing-the-FourGenerationsin-Todays-Workforce-Flager-Thompson.pdf (accessed on 12 January 2021).

80. Hayes, M.S.; Stazyk, E.C. Mission Congruence: To Agree or Not to Agree, and Its Implications for Public Employee Turnover. Public Pers. Manag. 2019, 48, 513-534. [CrossRef] 